\title{
Vegetation change and effects of cattle grazing in the transition mire "Burgmoos"
}

\author{
Helen Küchler • Andreas Grünig • Rolf Hangartner • \\ Meinrad Küchler
}

Received: 10 March 2009/Accepted: 5 October 2009/Published online: 3 November 2009

(C) Birkhäuser Verlag, Basel/Switzerland 2009

\begin{abstract}
Mires are highly threatened ecosystems in the lowlands of Central Europe. Reduced water levels and eutrophication promote shrub encroachment and the expansion of tall species, such as common reed (Phragmites australis). In the "Burgmoos", a Swiss mire of national importance, attempts have been made to reverse these developments through cattle grazing in parts of the mire area. To monitor overall vegetation change and to assess the influence of grazing (which started in 2004), the vegetation was surveyed in 1995, 2001 and 2007. Ecological indicator values of the vegetation changed considerably between 1995 and 2007: mean indicator values for nutrients and soil $\mathrm{pH}$ increased in 80 and $72 \%$ of the relevés, respectively, while mean indicator values for moisture, humus and light decreased in 81, 86 and $76 \%$ of the relevés, respectively. Plant species from bogs, transition mires and fens decreased, while trees, pasture species and $P$. australis increased. Grazing had a weak effect on $P$. australis and did not prevent an increase in abundance
\end{abstract}

Responsible editor: Sabine Güsewell.

H. Küchler $(\bowtie) \cdot$ M. Küchler

WSL, Swiss Federal Research Institute, Zürcherstrasse 111, 8903 Birmensdorf, Switzerland

e-mail: helen.kuechler@wsl.ch

M. Küchler

e-mail: meinrad.kuechler@wsl.ch

A. Grünig

ART, Swiss Federal Research Station, Reckenholzstrasse 191,

8046, Zurich, Switzerland

e-mail: andreas.gruenig@art.admin.ch

R. Hangartner

Köschenrütistrasse 147, 8052 Zurich, Switzerland

e-mail: r.j.hangartner@bluewin.ch of this species. The abundance of transition mire species was maintained in the grazed area between 2001 and 2007, whereas it continued to decrease in the ungrazed areas. This positive effect of grazing was, however, compensated by several adverse effects: In the non-forested parts of the mire, grazing accelerated the increase of nutrient indicator values, the decrease of bog species and the increase of pasture species. We conclude that grazing has not been effective in preventing undesirable vegetation changes in the Burgmoos.

Keywords Ecological indicator values - Galloway cattle · Phragmites australis · Vegetation monitoring ·

Wetland management

\section{Vegetationsveränderungen und Einfluss der Beweidung im Zwischenmoor "Burgmoos"}

Zusammenfassung Das "Burgmoos" liegt im Schweizer Mittelland und ist ein Zwischenmoor von nationaler Bedeutung. Um den charakteristischen Vegetationskomplex zu erhalten, wird das Moor seit den 1970er Jahren jährlich gemäht und seit 2004 teilweise beweidet. Anhand von Vegetationsaufnahmen der Jahre 1995, 2001 und 2007 untersuchten wir die Gesamtentwicklung des Moores und den Einfluss der Beweidung. Zwischen 1995 und 2007 haben sich die mittleren ökologischen Zeigerwerte der Vegetation stark verändert: die mittlere Nährstoffzahl stieg in $80 \%$ der Probeflächen und die Reaktionszahl in $72 \%$ der Probeflächen. Die mittleren Zeigerwerte für Feuchte, Humus und Licht nahmen in $81 \%$, 86\% bzw. $76 \%$ der Probeflächen ab. Die mittlere Affinität der vorkommenden 
Pflanzenarten zu Hochmoorarten, Übergangsmoorarten und Flachmoorarten nahm ab, während die Affinität zu Bäumen, Weidepflanzen und Schilf (Phragmites australis) zunahm. Beweidung verstärkte im Zentrum des Moors den Anstieg der mittleren Nährstoffzahl. Die Humuszahl sank in beweideten Flächen schneller als in unbeweideten. Die Abundanz der Hochmoorarten nahm in beweideten Flächen stärker $a b$, während die Weidezeiger von der Beweidung profitierten. Die Abundanz der Übergangsmoorarten blieb zwischen 2001 und 2007 auf den beweideten Flächen erhalten, während sie auf den unbeweideten Flächen weiter abnahm. Der Einfluss der Beweidung auf das Vorkommen von Schilf war statistisch nicht signifikant und geringer als die entsprechende gesamthafte Veränderung. Der ungünstige Einfluss der Beweidung auf die Vegetation, beschrieben durch die mittleren Zeigerwerte und Affinitäten, lag im gleichen Bereich wie die gesamthafte Veränderung dieser Parameter. Die Beweidung des Burgmoos muss deshalb optimiert oder unterlassen werden.

\section{Introduction}

Mires are species-rich habitats with a high proportion of rare species (Landolt 1991; Olde Venterink and Vittoz 2008). All over Central Europe, these communities are endangered due to hydrological change, eutrophication and reduced management (Bokdam and Gleichman 2000). In many lowland mires, shrub encroachment and a spread of common reed (Phragmites australis) have been observed in the last decades. These tall plants additionally threaten the mire vegetation as they might displace typical fen or bog species (Güsewell and Klötzli 1998). Grazing by cattle has increasingly been introduced to manage the vegetation in nature reserves (Stammel et al. 2003; Güsewell et al. 2007). While grazing is a means to control the spread of common reed, it may also lead to an unintended change in the composition of the vegetation (Bokdam and Gleichman 2000). As Middleton et al. (2006) showed, overgrazing results in a permanent reduction of species richness. The introduction of cattle must, therefore, be done with care.

We chose the "Burgmoos", a Swiss mire of national importance, to explore the effect of grazing on mire vegetation. Previous vegetation studies have shown that the mire has recently developed towards more acidic, drier and increasingly nutrient-rich conditions (Höhn-Ochsner 1963; Kunz-Hasler 1990, unpublished thesis at the University of Berne). During the past few decades, common reed (P. australis) and alder (Alnus glutinosa) progressively invaded the mire. The Burgmoos has been regularly mown since the 1970ies to keep its character of a transition mire.
However, reed and shrub invasion continued. Therefore, parts of the mire have been grazed by Galloway cattle since 2004 in order to control reed invasion more effectively.

The present study is based on vegetation surveys carried out in the mire in 1995, 2001 and 2007. We address the following questions:

- Did the previously reported change towards more acidic, drier and more nutrient rich conditions in the "Burgmoos" continue after 1995?

- Which species have increased and which ones have become less abundant?

- Did the trends in species composition differ between the grazed and ungrazed areas?

- How did grazing affect the abundance of individual plant species, especially $P$. australis?

\section{Methods}

Study area

The mire "Burgmoos" is situated in the Swiss Plateau between Herzogenbuchsee and Solothurn at an altitude of $465 \mathrm{~m}$ a.s.1. The site is located north-east of the Burgäschi lake.

The basin of the Burgmoos was formed during the last glacial period when it became filled with dead ice. When the ice eventually melted, a lake remained. The mire developed by aggradation of this former lake, partly through mineral deposits, partly through the formation of peat (Baumberger 1911). In 1942-1943, the water level of the Burgäschi lake was lowered as part of a drainage scheme (Von Büren 1949). This also influenced the hydrology of the nearby Burgmoos.

Despite its small size, the Burgmoos is today the most species-rich mire in the Swiss Plateau (Grossenbacher 1980). It consists of several vegetation types: ombrotrophic bog, transition mire, fen, tall-forb stands and forest (HöhnOchsner 1963). The mire has been protected since 1944. It is very isolated from other mires in the Swiss Plateau. Accordingly, great efforts have been made to preserve its character of a transition mire.

\section{Vegetation surveys}

Our data set consists of vegetation records from 157 patches covering the whole surface of the mire. Prior to field work, patches were delineated on aerial photographs, such that homogeneity in terms of colour and structure within a patch could be maximized (Küchler et al. 2004). Of these 157 patches, 76 are open vegetation ("centre"), and 81 are from the wooded border area ("border") (Fig. 1). 


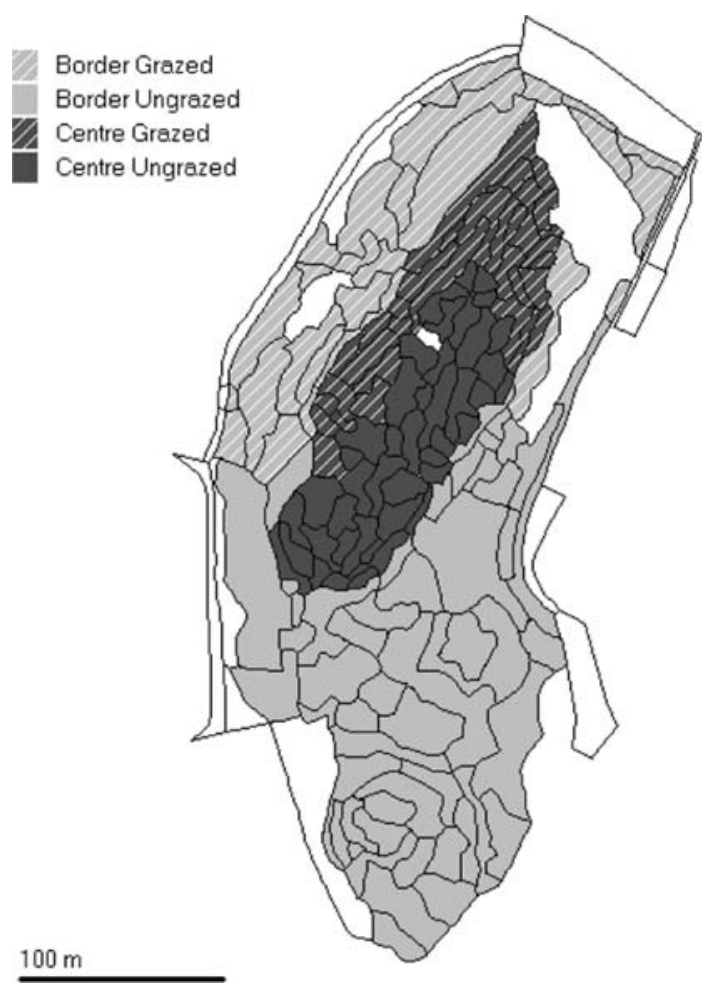

Fig. 1 Patches in the Burgmoos: centre (dark grey), border area (light grey), grazed patches (hatched), patches where data are missing in one or more surveys (white)

Part of the Burgmoos has been grazed by Galloway cattle since 2004. In the central area 33 patches were grazed, whereas 43 patches were protected from grazing by a fence. In the border area 29 patches were grazed and 52 were not grazed (Fig. 1). The grazing regime was varied slightly over the years; in average about five heifers grazed in the Burgmoos during 11 weeks (starting in June), 7 weeks in the border area and in between 4 weeks in the centre. The non-forested part of the mire was further mown in autumn for maintenance.

Vegetation surveys were carried out in 1995, 2001 and 2007. The abundance of vascular plant and bryophyte species in each of the 157 patches was estimated on a logarithmic scale from 1 to 4 , where " 1 " denotes less than $0.1 \%$ cover, " 2 " denotes $0.1-1 \%$ cover, " 3 " denotes $1-10 \%$ cover, and " 4 " denotes more than $10 \%$ cover. For calculations the codes were transformed to mean percentage cover as follows: " $1 "=0.03 \%, " 2 "=0.32 \%$, $" 3 "=3.16 \%, " 4 "=31.62 \%$.

Assessment of ecological conditions

To assess changes in ecological conditions based on the vegetation data, we used the ecological indicator values for vascular plants of Switzerland (Landolt 1977). These are scaled in ordinal levels from 1 to 5 for moisture, light, nutrients, soil reaction and humus content. Küchler et al. (2004) calibrated them for mire habitats on the basis of 20,000 relevés from the Swiss mire monitoring program. The scale of these adjusted values is continuous. We computed the $10 \%$-trimmed means of the indicator values for all records in the three surveys. The 10\%-trimming, i.e. excluding the $10 \%$ highest and the $10 \%$ lowest values in the concerned data, was applied to enhance the robustness against extreme observations.

We further developed an alternative approach for the assessment of ecological conditions, which was not based on expert opinion but on detailed records of species cooccurrences in the 20,000 vegetation relevés from the Swiss mire monitoring program. The idea was to evaluate the ecological suitability ("affinity") of vegetation patches for particular target species based on the list of species present in the patch and their co-occurrences with the target species in the 20,000 reference relevés. The affinity of a given species $S 1$ to a target species $S_{\mathrm{t}}$ was defined as the probability that $S_{\mathrm{t}}$ would occur if $S 1$ is present $\left(=P\left(S_{\mathrm{t}} \mid S 1\right)\right)$. We estimated this probability from the quotient $a /(a+b)$, where $\mathrm{a}$ is the number of reference relevés with common occurrence of both species, and b is the number of relevés where $S 1$ is present but $S_{\mathrm{t}}$ is absent.

The ecological suitability of a patch for the target species $S_{\mathrm{t}}$ was assessed by the $10 \%$-trimmed mean of the affinity values of all species recorded in the patch to $S_{\mathrm{t}}$. The overall change in ecological conditions for the target species $S_{\mathrm{t}}$ was assessed by comparing the mean of the affinity values of all patches to this species among the three surveys. Patches with affinities to $S_{\mathrm{t}}$ lower than $0.1(=10 \%)$ in all three surveys were excluded from the analysis of change so that conclusions about ecological conditions for a species would only be derived from patches where this species had a chance to occur. We computed affinity values for all vascular plant species that are frequent in the Burgmoos and representative of certain vegetation types or growth forms (see grouping given in the next section or Table 2).

\section{Abundance of species groups}

To describe the vegetation composition of a patch, the percentage cover of each plant species was divided by the sum of cover values of all species in the patch to obtain relative abundance values. For the analysis and interpretation of vegetation change, we considered the sum of relative abundance values for groups of species that are typical of a particular vegetation type, growth form or management. Patches with a relative abundance of $0 \%$ for a certain species group in all three surveys were excluded from the analysis of change for this group. The groups analysed were: 
- Bog: Andromeda polifolia, Drosera rotundifolia, Eriophorum vaginatum, Vaccinium oxycoccos, Polytrichum strictum, Sphagnum magellanicum

- Transition mire: Carex lasiocarpa, Carex limosa, Eriophorum angustifolium, Eriophorum gracile, Menyanthes trifoliata, Potentilla palustris, Rhynchospora alba, Scheuchzeria palustris

- Fen: Carex panicea, Epilobium palustre, Equisetum fluviatile, Lysimachia thyrsiflora, Molinia caerulea, Parnassia palustris, Succisa pratensis

- Tall forbs: Angelica sylvestris, Eupatorium cannabinum, Filipendula ulmaria, Lycopus europaeus, Lysimachia vulgaris, Lythrum salicaria

- Trees: Alnus glutinosa, Betula pubescens

- Reed: Phragmites australis

- Peat mosses: Sphagnum spp. The abundance of these species, typical of bogs and poor fens, was quantified by their proportion of the total cover of all bryophytes.

- Pasture: Anthoxanthum odoratum, Holcus lanatus, Lathyrus pratensis, Poa trivialis

\section{Statistical analysis}

To assess the overall change in vegetation in the Burgmoos, we computed the differences in the various variables between 1995 and 2007. From these calculations we obtained the differences $d_{07-95}$ in the indicator values, the mean affinity to single target species and the relative abundance of species groups. To test their significance, we used the Wilcoxon rank sum test as implemented in the computer program VEGEDAZ (Küchler 2008), with Bonferroni correction for multiple testing if necessary. For affinity values, the test was only applied if at least five records with data were available after excluding the patches with low values for a particular target species.

All analyses were performed for the whole mire and separately for the centre and the border (Fig. 1). Since data had been collected in adjacent patches (Fig. 1), spatial autocorrelation was likely to occur. A spherical correlogram (Venables and Ripley 2002) gave a range of about $60 \mathrm{~m}$ for the mean indicator values. Therefore, the given $P$ values may underestimate the true error probabilities in stating significant changes; they have to be interpreted as an additional illustration of the changes, rather than a strict conclusive statistic.

To assess the influence of grazing, we compared grazed and ungrazed patches. We computed the differences in values of the variables between 1995 and $2001\left(d_{01-95}\right)$, and between 2001 and $2007\left(d_{07-01}\right)$ separately for grazed and ungrazed patches. Grazing started in 2004, so that if grazing had an impact, this would become evident in the course of the second period. If the grazed and ungrazed patches developed similarly in the first period but differently in the second period, we considered this as evidence for grazing having an impact. More generally, if the development of the grazed patches compared with the ungrazed patches changed between the first and second period, an influence of grazing could be assumed. To test such effects, we computed the differences between the changes in the first and in the second period $\left(d_{\mathrm{d}}=\right.$ $d_{07-01}-d_{01-95}$ ), separately for the grazed and the ungrazed patches (Table 4). If $d_{\mathrm{d}}$ (e.g. of the nutrient value) was greater for grazed patches than for ungrazed patches, we conclude that grazing promoted an increase in the (nutrient) value. We used the Wilcoxon rank sum test again to compare the differences $d_{\mathrm{d}}$ of the two groups.

In disturbed areas, the interpretation of mean indicator values as a surrogate for measured site conditions may be invalid, since species may occur temporarily at places that do not correspond to their main habitats (Landolt 1977). In the "Burgmoos", changes in mean indicator values may result from the transport of plants or propagules by cattle moving from one place to another, without necessarily altering the site conditions. Such possible effects were checked whenever a test result showed a significant impact of grazing on an indicator value. The check consisted in repeating the calculations after excluding species which were probably brought in by cattle. We excluded the species found mainly (i.e. at least $50 \%$ of the findings) in the grazed area in 2007. Additionally we removed rare species with less than three occurrences in the whole data set.

\section{Results}

Overall change between 1995 and 2007

The mean indicator value for moisture, light and humus decreased in most patches between 1995 and 2007, whereas the mean nutrient value increased in the majority of the patches. All indicator values changed significantly across the whole mire area (Table 1). Changes were similar in the non-forested centre and in the forested border area (Table 1).

The mean affinity to bog species decreased from 1995 to 2007 (Table 2). For example, the mean affinity to Andromeda polifolia decreased in $81 \%$ of the patches. This means that species with high affinity to A. polifolia have decreased since 1995 , or that species with low affinity to A. polifolia have increased. Likewise, the mean affinity to species typical of transition mires and fens and to tree species decreased. Conversely, the mean affinity to tall forbs, pasture species and common reed ( $P$. australis) 
Table 1 Change in the indicator values from 1995 till 2007

\begin{tabular}{|c|c|c|c|c|c|c|c|c|c|}
\hline & \multicolumn{3}{|c|}{ Whole area $(N=157)$} & \multicolumn{3}{|c|}{ Centre $(N=76)$} & \multicolumn{3}{|c|}{ Border $(N=81)$} \\
\hline & 1995 & $d_{07-95}$ & Incr. $(\%)$ & 1995 & $d_{07-95}$ & Incr. $(\%)$ & 1995 & $d_{07-95}$ & Incr. $(\%)$ \\
\hline Moisture & 3.96 & $-0.13 * * *$ & 19 & 4.30 & $-0.13 * * *$ & 12 & 3.63 & $-0.13 * * *$ & 26 \\
\hline Light & 3.30 & $-0.09 * * *$ & 24 & 3.69 & $-0.10 * * *$ & 12 & 2.93 & $-0.07 * *$ & 35 \\
\hline Soil reaction & 2.82 & $+0.12 * * *$ & 72 & 2.54 & $+0.15^{* * *}$ & 74 & 3.08 & $+0.09 * * *$ & 70 \\
\hline Nutrients & 2.55 & $+0.17 * * *$ & 80 & 2.07 & $+0.20 * * *$ & 84 & 2.99 & $+0.14 * * *$ & 75 \\
\hline Humus & 4.20 & $-0.17 * * *$ & 14 & 4.67 & $-0.21 * * *$ & 11 & 3.76 & $-0.14 * * *$ & 17 \\
\hline
\end{tabular}

Differences between 1995 and 2007 were tested with paired Wilcoxon rank sum tests with Bonferroni correction: $* P<0.05 ; * * P<0.01$; *** $P<0.001$

Incr. percentage of patches with increased values

increased. Trends were similar in the centre and border of the mire (Table 2).

The relative abundance of species groups changed significantly for most groups (Table 3). Species characteristic of bogs, transition mires and fens as well as peat mosses decreased. Conversely, pasture species, trees and common reed increased. Again, trends in the centre and in the border of the mire were similar.

\section{Effects of grazing}

In the centre of the mire, the mean nutrient indicator values of the vegetation increased similarly in grazed and ungrazed patches during the first period (1995-2001). In the second period (2001-2007), however, the nutrient value increased significantly faster in the grazed patches than in the ungrazed ones, suggesting an increase in nutrient availability due to grazing (Fig. 2). In the border area, the nutrient value also changed differently in grazed and ungrazed patches, but in the opposite way: Between 2001 and 2007, the nutrient value tended to decrease in the grazed patches, whereas it continued to increase in the ungrazed patches (Fig. 2). Furthermore, the mean humus value decreased significantly faster in the grazed patches than in the ungrazed ones in the centre of the mire (Table 4). After excluding the species probably brought in by cattle, the differences between grazed and ungrazed patches $\left(d_{\text {dgrazed }}-d_{\text {dungrazed }}\right)$ in the development of nutrient and humus values were reduced by 0.06 and 0.05 , respectively.

The mean affinity of vegetation patches to Andromeda polifolia, Eriophorum vaginatum, Polytrichum strictum, Menyanthes trifoliata and Molinia caerulea decreased faster in grazed than in ungrazed patches in the centre of the mire (Table 4). This suggests that ecological conditions for these bog and fen species deteriorated faster with grazing. Concomitantly, changes in affinity values suggest that grazing improved the ecological conditions for Carex panicea, Anthoxanthum odoratum, Holcus lanatus, Poa trivialis and Lathyrus pratensis (Table 4).
The abundance of species groups also changed differently in grazed and ungrazed patches (Table 4). The proportion of bog species generally increased between 1995 and 2001 and decreased between 2001 and 2007 (Fig. 3). The decrease during the second period was faster in the grazed patches than in the ungrazed ones (Fig. 3; Table 4). The proportion of species from transition mires generally decreased between 1995 and 2001. Between 2001 and 2007, it remained stable in the grazed patches, whereas it continued to decrease in the ungrazed patches (Fig. 3; Table 4). Trees (A. glutinosa and Betula pubescens) decreased in the grazed patches compared with ungrazed ones in the centre of the mire (Table 4). Pasture species increased since 2001 in the grazed patches compared with ungrazed ones (Table 4).

Common reed ( $P$. australis) was less abundant in the grazed area even before grazing started. Throughout the observation period (1995-2007), its abundance increased less in the grazed patches than in the ungrazed ones (Fig. 3). Therefore, an influence of grazing on the abundance of Phragmites could not be proved. The differences $d_{\mathrm{d}} \quad\left(d_{07-01}-d_{01-95}\right)$ were not significantly different between grazed and ungrazed patches.

\section{Discussion}

Overall change

The changes in ecological indicator values indicate that the trend towards drier and increasingly nutrient-rich conditions reported earlier (Höhn-Ochsner 1963, Kunz-Hasler 1990, unpublished thesis) has continued. The increased nutrient values may be largely the result of peat decomposition due to drier conditions. Nutrient input from the air and from the nearby agricultural area may have also taken place. The ongoing tree encroachment and the hot summer in 2003 may have contributed to the drier conditions (Edom et al. 2007; Bragazza 2008). On the other hand, 
Table 2 Changes in the mean affinity of the vegetation to single species from 1995 till 2007

\begin{tabular}{|c|c|c|c|c|c|c|c|c|c|c|c|c|}
\hline & \multicolumn{4}{|c|}{ Whole area } & \multicolumn{4}{|c|}{ Centre } & \multicolumn{4}{|c|}{ Border } \\
\hline & $N$ & 1995 & $d_{07-95}$ & Incr. $(\%)$ & $N$ & 1995 & $d_{07-95}$ & Incr. $(\%)$ & $N$ & 1995 & $d_{07-95}$ & Incr. $(\%)$ \\
\hline \multicolumn{13}{|l|}{ Bog } \\
\hline Andromeda polifolia & 37 & 13.1 & $-2.4 * * *$ & 19 & 34 & 13.2 & $-2.2 * * *$ & 21 & & & & \\
\hline Drosera rotundifolia & 78 & 17.7 & $-3.7 * * *$ & 15 & 68 & 18.2 & $-3.6 * * *$ & 18 & 10 & 14.0 & $-4.6 *$ & 0 \\
\hline Eriophorum vaginatum & 122 & 26.1 & $-4.5 * * *$ & 16 & 75 & 30.3 & $-4.3 * * *$ & 21 & 47 & 19.3 & $-4.9 * * *$ & 6 \\
\hline Vaccinium oxycoccos & 68 & 15.2 & $-3.0 * * *$ & 16 & 59 & 15.6 & $-2.9 * * *$ & 17 & 9 & 12.3 & -3.5 & 11 \\
\hline Polytrichum strictum & 119 & 24.3 & $-4.4 * * *$ & 14 & 75 & 27.7 & $-4.2 * * *$ & 19 & 44 & 18.6 & $-4.6 * * *$ & 7 \\
\hline Sphagnum magellanicum & 122 & 25.0 & $-4.1 * * *$ & 25 & 75 & 28.3 & $-3.9 * * *$ & 28 & 47 & 19.6 & $-4.5 * * *$ & 19 \\
\hline \multicolumn{13}{|l|}{ Transition mire } \\
\hline Carex lasiocarpa & 11 & 10.4 & -1.2 & 18 & 11 & 10.4 & -1.2 & 18 & & & & \\
\hline Carex limosa & 6 & 10.0 & -1.9 & 0 & 6 & 10.0 & -1.9 & 0 & & & & \\
\hline Eriophorum angustifolium & 136 & 24.3 & $-3.0 * * *$ & 23 & 76 & 31.1 & $-3.1 * * *$ & 22 & 60 & 15.6 & $-2.7 * * *$ & 23 \\
\hline Menyanthes trifoliata & 83 & 15.2 & $-2.2 * * *$ & 14 & 73 & 15.7 & $-2.2 * * *$ & 15 & 10 & 11.4 & $-2.6^{*}$ & 10 \\
\hline Potentilla palustris & 52 & 11.1 & $-1.7 * * *$ & 13 & 51 & 11.2 & $-1.6^{* * *}$ & 14 & & & & \\
\hline \multicolumn{13}{|l|}{ Fen } \\
\hline Carex panicea & 157 & 33.2 & -0.7 & 46 & 76 & 37.4 & +0.3 & 54 & 81 & 29.3 & $-1.6^{*}$ & 38 \\
\hline Epilobium palustre & 117 & 12.1 & -0.1 & 52 & 70 & 12.3 & $+0.7 *$ & 64 & 47 & 11.7 & $-1.2 * *$ & 34 \\
\hline Equisetum fluviatile & 53 & 10.1 & -0.2 & 43 & 46 & 10.0 & -0.1 & 48 & 7 & 10.8 & -1.4 & 14 \\
\hline Molinia caerulea & 157 & 49.3 & $-2.7 * * *$ & 25 & 76 & 57.4 & $-3.0 * * *$ & 22 & 81 & 41.7 & $-2.4 * * *$ & 27 \\
\hline Parnassia palustris & 90 & 14.4 & $-1.5 * * *$ & 21 & 75 & 14.9 & $-1.4 * * *$ & 21 & 15 & 11.5 & $-2.4^{*}$ & 20 \\
\hline Succisa pratensis & 157 & 21.7 & $-0.9 * * *$ & 39 & 76 & 25.3 & -0.4 & 41 & 81 & 18.4 & $-1.3 * *$ & 37 \\
\hline \multicolumn{13}{|l|}{ Tall forbs } \\
\hline Angelica sylvestris & 157 & 18.1 & $+0.7 * * *$ & 67 & 76 & 14.3 & $+1.0 * * *$ & 75 & 81 & 21.7 & +0.4 & 59 \\
\hline Filipendula ulmaria & 157 & 33.2 & $+2.2 * * *$ & 69 & 76 & 26.7 & $+3.0 * * *$ & 76 & 81 & 39.3 & $+1.6^{*}$ & 62 \\
\hline Lysimachia vulgaris & 144 & 16.7 & +0.2 & 57 & 64 & 13.3 & +1.3 & 67 & 80 & 19.4 & -0.7 & 49 \\
\hline Lythrum salicaria & 121 & 12.8 & -0.1 & 51 & 49 & 11.1 & +0.7 & 59 & 72 & 14.0 & -0.6 & 46 \\
\hline \multicolumn{13}{|l|}{ Trees } \\
\hline Alnus glutinosa & 10 & 9.7 & -0.1 & 50 & & & & & 10 & 9.7 & -0.1 & 50 \\
\hline Betula pubescens & 147 & 14.0 & $-0.5^{*}$ & 46 & 74 & 13.9 & $-1.0 * * *$ & 31 & 73 & 14.2 & 0.0 & 60 \\
\hline \multicolumn{13}{|l|}{ Reed } \\
\hline Phragmites australis & 140 & 19.6 & $+1.1 * *$ & 61 & 62 & 13.8 & $+2.7 * * *$ & 69 & 78 & 24.3 & -0.1 & 55 \\
\hline \multicolumn{13}{|l|}{ Pasture } \\
\hline Anthoxanthum odoratum & 157 & 41.9 & +1.2 & 54 & 76 & 42.7 & $+2.5^{* * *}$ & 71 & 81 & 41.2 & 0.0 & 38 \\
\hline Holcus lanatus & 136 & 15.4 & $+1.4 * * *$ & 71 & 57 & 12.3 & $+1.9 * * *$ & 75 & 79 & 17.6 & $+1.1^{*}$ & 68 \\
\hline Lathyrus pratensis & 137 & 17.3 & $+1.6 * * *$ & 67 & 59 & 13.7 & $+2.8 * * *$ & 81 & 78 & 20.1 & +0.6 & 56 \\
\hline Poa trivialis & 145 & 20.3 & $+2.8 * * *$ & 79 & 64 & 13.4 & $+3.8 * * *$ & 83 & 81 & 25.7 & $+2.1 * * *$ & 75 \\
\hline
\end{tabular}

Differences between 1995 and 2007 were tested with paired Wilcoxon rank sum tests with Bonferroni correction: $* P<0.05$; ** $P<0.01$; *** $P<0.001$

Incr. percentage of patches with increased values, empty fields insufficient data for testing

contrary to previous reports, the Burgmoos did no longer develop more acidic conditions. Nutrient inputs and peat decomposition following water loss probably reduced the acidification. The proportion of peat mosses in the bryophyte layer has also decreased, which possibly reduced the acidifying effect of bryophytes (Kooijman and Bakker 1994).

Our results confirm that the ecological suitability for the species of bog, transition mire and fen species has decreased, whereas it has increased for pasture species, tall forbs and trees. Despite the observed decrease in the mean moisture indicator value, $P$. australis has spread since 1995, and especially since 2001 (Fig. 3). The aboveground biomass of Phragmites has been shown to positively correlate with the nitrogen indicator value of the vegetation, but not with the soil moisture indicator value (Güsewell and Klötzli 1998). Since Phragmites can reach the groundwater table with its rhizomes down to $1.5 \mathrm{~m}$ or 
Table 3 Changes in the proportions of species groups from 1995 till 2007

\begin{tabular}{|c|c|c|c|c|c|c|c|c|c|c|c|c|}
\hline & \multicolumn{4}{|c|}{ Whole area } & \multicolumn{4}{|c|}{ Centre } & \multicolumn{4}{|c|}{ Border } \\
\hline & $N$ & 1995 & $d_{07-95}$ & Incr. (\%) & $N$ & 1995 & $d_{07-95}$ & Incr. $(\%)$ & $N$ & 1995 & $d_{07-95}$ & Incr. $(\%)$ \\
\hline Bog & 83 & 27.8 & $-4.1 *$ & 42 & 70 & 30.9 & -3.6 & 44 & 13 & 10.7 & $-6.8 *$ & 31 \\
\hline Transition mire & 91 & 14.5 & $-7.8^{* * *}$ & 37 & 74 & 17.3 & $-9.2 * * *$ & 38 & 17 & 2.4 & -1.6 & 35 \\
\hline Fen & 129 & 9.0 & $-3.1 * *$ & 46 & 76 & 10.9 & -1.8 & 47 & 53 & 6.4 & $-5.0 * * *$ & 43 \\
\hline Tall forbs & 130 & 3.6 & -2.0 & 55 & 59 & 3.5 & -0.8 & 64 & 71 & 3.7 & $-3.1^{*}$ & 46 \\
\hline Trees & 139 & 6.8 & $+3.6^{* * *}$ & 76 & 74 & 3.0 & $+0.9 * * *$ & 78 & 65 & 11.2 & $+6.6^{* * *}$ & 74 \\
\hline Reed & 113 & 4.0 & $+3.0 * * *$ & 70 & 76 & 4.8 & $+4.9 * * *$ & 80 & 37 & 2.3 & -0.7 & 49 \\
\hline Peat mosses & 114 & 73.9 & $-17.9 * * *$ & 19 & 71 & 89.2 & $-13.3^{* * *}$ & 21 & 43 & 48.7 & $-25.4 * * *$ & 16 \\
\hline Pasture & 92 & 0.8 & $+4.3 * * *$ & 93 & 44 & 0.1 & $+1.2 * * *$ & 93 & 48 & 1.4 & $+7.1 * * *$ & 94 \\
\hline
\end{tabular}

Differences between 1995 and 2007 were tested with paired Wilcoxon rank sum tests: * $P<0.05$; ** $P<0.01$; *** $P<0.001$ Incr. Percentage of patches with increased values

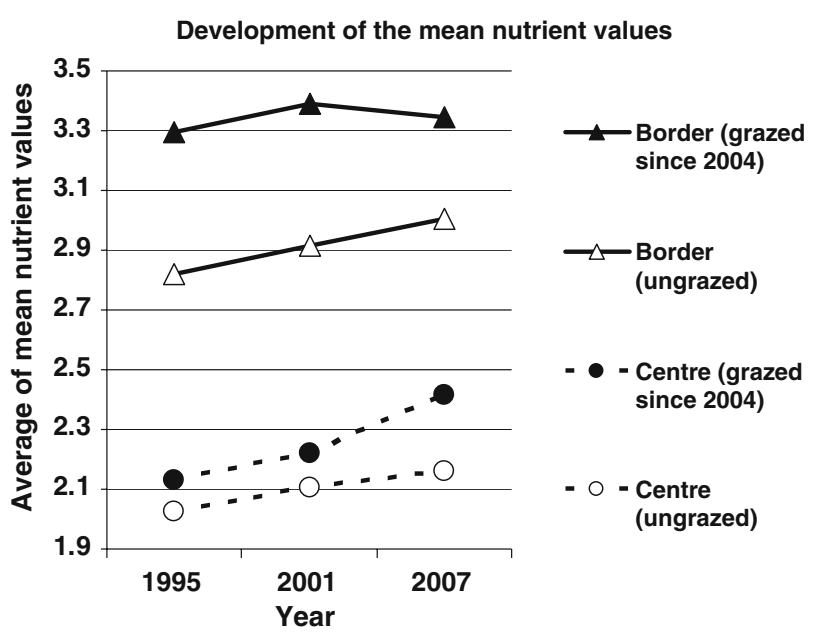

Fig. 2 Changes in mean nutrient indicator values of the vegetation in grazed and ungrazed patches within the forested border and the nonforested centre of the mire

more, it may grow fairly well at sites drying out close to the surface (Haslam 1972). This may explain why it has become more abundant in spite of the drier conditions.

Contradictory results were obtained for changes in the abundance of trees. The vegetation composition indicated a decreasing suitability for Betula and Alnus, whereas their actual abundance has increased. Not only can the roots of shrubs and trees grow more deeply into the soil that those of herbaceous species; their spread is also highly dependent on management.

\section{Effects of grazing}

In the central part of the mire, grazing accelerated the increase of the mean nutrient value and the decrease of the humus value. The influence of grazing on the nutrient value was similar to the overall changes observed between 1995 and 2007. For example, in the ungrazed patches of the centre, the mean nutrient value increased by 0.14 between 1995 and 2007, while the difference between grazed and ungrazed patches in the change from 2001 to 2007 was 0.13 .

Grazing also had negative effects on the vegetation. In the grazed patches the conditions for bog species deteriorated faster than in the ungrazed patches, whereas pasture species increased significantly faster in the grazed patches (Table 4). The only positive effect of grazing regarded the abundance of transition-mire species, which remained about constant in the grazed patches of the centre, whereas they continued to decrease in the ungrazed patches. However, considering the overall changes in site conditions and vegetation, this positive impact is unlikely to be sustainable.

The tendency for Phragmites to spread more slowly in the grazed patches during the grazing period indicates that grazing might inhibit the spread of Phragmites, but it was not sufficient to stop the invasion completely. Furthermore, the estimated effect of grazing was smaller than the overall change in Phragmites abundance (Table 4). An important restriction to these results is that they are based on percentage cover and do not take into account the size of the shoots, which is essential for the shading effect of Phragmites on other species, and which tends to be reduced by management (Güsewell 2003).

Recommendations for conservation management

Grazing was introduced in 2004 to reduce invasion by $P$. australis. The disturbance caused by grazing appeared to be stronger than the inhibitive effect on $P$. australis. There was some success in maintaining the transition-mire species, but in general, the present grazing regime appeared to cause more harm than benefit. If grazing is to be continued, the grazing regime should be optimized to reduce trampling, 
Table 4 Effects of grazing on changes in vegetation properties

\begin{tabular}{|c|c|c|c|c|c|c|c|c|}
\hline & $N$ & 1995 & 2001 & 2007 & $d_{01-95}$ & $d_{07-01}$ & $d_{\mathrm{d}}=d_{07-01}-d_{01-95}$ & $d_{\text {dgrazed }}-d_{\text {dungrazed }}$ \\
\hline \multicolumn{9}{|l|}{ Mean indicator values } \\
\hline \multicolumn{9}{|l|}{ Mean nutrient value } \\
\hline Border, grazed & 29 & 3.29 & 3.39 & 3.34 & +0.10 & -0.05 & -0.15 & \multirow[t]{2}{*}{$-0.14 *$} \\
\hline Border, ungrazed & 52 & 2.82 & 2.92 & 3.00 & +0.09 & +0.09 & -0.01 & \\
\hline Centre, grazed & 33 & 2.13 & 2.22 & 2.41 & +0.09 & +0.20 & 0.11 & \multirow[t]{2}{*}{$0.13 *$} \\
\hline Centre, ungrazed & 43 & 2.03 & 2.10 & 2.16 & +0.08 & +0.06 & -0.02 & \\
\hline \multicolumn{9}{|l|}{ Mean humus value } \\
\hline Centre, grazed & 33 & 4.60 & 4.53 & 4.34 & -0.07 & -0.19 & -0.12 & \multirow[t]{2}{*}{$-0.12 * *$} \\
\hline Centre, ungrazed & 43 & 4.72 & 4.63 & 4.55 & -0.09 & -0.09 & 0.00 & \\
\hline \multicolumn{9}{|l|}{ Mean affinity values } \\
\hline \multicolumn{9}{|l|}{ Andromeda polifolia } \\
\hline Centre, grazed & 9 & 11.4 & 12.5 & 9.1 & +1.1 & -3.4 & -4.4 & \multirow[t]{2}{*}{$-3.5^{*}$} \\
\hline Centre, ungrazed & 25 & 13.8 & 13.1 & 11.6 & -0.6 & -1.5 & -0.9 & \\
\hline \multicolumn{9}{|c|}{ Eriophorum vaginatum } \\
\hline Centre, grazed & 33 & 27.2 & 26.8 & 21.9 & -0.4 & -4.9 & -4.4 & \multirow[t]{2}{*}{$-3.1^{*}$} \\
\hline Centre, ungrazed & 42 & 32.7 & 31.6 & 29.2 & -1.1 & -2.5 & -1.3 & \\
\hline \multicolumn{9}{|l|}{ Polytrichum strictum } \\
\hline Centre, grazed & 33 & 25.8 & 24.5 & 20.1 & -1.3 & -4.4 & -3.1 & \multirow[t]{2}{*}{$-2.5^{*}$} \\
\hline Centre, ungrazed & 42 & 29.1 & 27.9 & 26.1 & -1.2 & -1.9 & -0.6 & \\
\hline \multicolumn{9}{|l|}{ Menyanthes trifoliata } \\
\hline Centre, grazed & 32 & 15.1 & 14.1 & 12.5 & -1.0 & -1.7 & -0.7 & \multirow[t]{2}{*}{$-1.7 * *$} \\
\hline Centre, ungrazed & 41 & 16.1 & 14.7 & 14.3 & -1.4 & -0.4 & 1.0 & \\
\hline \multicolumn{9}{|l|}{ Molinia caerulea } \\
\hline Centre, grazed & 33 & 57.3 & 55.7 & 52.1 & -1.6 & -3.6 & -2.0 & \multirow[t]{2}{*}{$-2.5 * *$} \\
\hline Centre, ungrazed & 43 & 57.5 & 56.6 & 56.2 & -0.9 & -0.4 & 0.5 & \\
\hline \multicolumn{9}{|l|}{ Carex panicea } \\
\hline Centre, grazed & 33 & 38.6 & 37.1 & 39.1 & -1.5 & +2.1 & 3.6 & \multirow[t]{2}{*}{$+2.1^{*}$} \\
\hline Centre, ungrazed & 43 & 36.4 & 35.7 & 36.5 & -0.7 & +0.8 & 1.5 & \\
\hline \multicolumn{9}{|c|}{ Anthoxanth. odoratum } \\
\hline Centre, grazed & 33 & 42.6 & 43.3 & 46.8 & +0.7 & +3.5 & 2.8 & \multirow[t]{2}{*}{$+3.1^{*}$} \\
\hline Centre, ungrazed & 43 & 42.7 & 43.4 & 43.9 & +0.7 & +0.4 & -0.3 & \\
\hline Holcus lanatus & & & & & & & & \\
\hline Centre, grazed & 32 & 11.7 & 11.9 & 14.3 & +0.2 & +2.3 & 2.1 & $+1.9^{*}$ \\
\hline Centre, ungrazed & 25 & 13.1 & 13.6 & 14.2 & +0.4 & +0.7 & 0.2 & \\
\hline Poa trivialis & & & & & & & & \\
\hline Centre, grazed & 33 & 12.8 & 14.3 & 18.2 & +1.4 & +4.0 & 2.5 & $+2.5 * *$ \\
\hline Centre, ungrazed & 31 & 14.0 & 15.0 & 16.0 & +1.0 & +1.0 & 0.0 & \\
\hline Lathyrus pratensis & & & & & & & & \\
\hline Centre, grazed & 31 & 13.1 & 13.7 & 16.7 & +0.6 & +3.0 & 2.4 & $+2.2 *$ \\
\hline Centre, ungrazed & 28 & 14.4 & 15.3 & 16.3 & +0.8 & +1.1 & 0.2 & \\
\hline Proportions of specie & bups & & & & & & & \\
\hline Bog & & & & & & & & \\
\hline Centre, grazed & 30 & 28.3 & 34.9 & 19.1 & +6.6 & -15.8 & -22.3 & $-15.4 *$ \\
\hline Centre, ungrazed & 40 & 32.9 & 36.6 & 33.6 & +3.8 & -3.1 & -6.9 & \\
\hline Tansition mire & & & & & & & & \\
\hline Centre, grazed & 32 & 17.6 & 7.5 & 8.8 & -10.1 & +1.3 & +11.4 & $+12.6 * *$ \\
\hline Centre, ungrazed & 42 & 17.0 & 12.9 & 7.5 & -4.1 & -5.3 & -1.2 & \\
\hline
\end{tabular}


Table 4 continued

\begin{tabular}{|c|c|c|c|c|c|c|c|c|}
\hline & $N$ & 1995 & 2001 & 2007 & $d_{01-95}$ & $d_{07-01}$ & $d_{\mathrm{d}}=d_{07-01}-d_{01-95}$ & $d_{\text {dgrazed }}-d_{\text {dungrazed }}$ \\
\hline \multicolumn{9}{|l|}{ Fen } \\
\hline Centre, grazed & 33 & 11.5 & 7.6 & 7.9 & -3.9 & +0.3 & +4.2 & \multirow[t]{2}{*}{-4.4} \\
\hline Centre, ungrazed & 43 & 10.4 & 5.9 & 10.0 & -4.5 & +4.1 & +8.6 & \\
\hline \multicolumn{9}{|l|}{ Tall forbs } \\
\hline Centre, grazed & 30 & 3.4 & 4.9 & 2.8 & +1.5 & -2.1 & -3.6 & \multirow[t]{2}{*}{-1.3} \\
\hline Centre, ungrazed & 29 & 3.5 & 4.1 & 2.4 & +0.6 & -1.7 & -2.3 & \\
\hline \multicolumn{9}{|l|}{ Trees } \\
\hline Centre, grazed & 33 & 5.7 & 6.7 & 4.5 & +1.0 & -2.1 & -3.1 & \multirow[t]{2}{*}{$-3.6^{*}$} \\
\hline Centre, ungrazed & 41 & 0.8 . & 1.8 & 3.3 & +1.0 & +1.5 & +0.5 & \\
\hline \multicolumn{9}{|l|}{ Reed } \\
\hline Centre, grazed & 33 & 3.2 & 1.3 & 5.6 & -1.9 & +4.3 & +6.1 & \multirow[t]{2}{*}{-1.5} \\
\hline Centre, ungrazed & 43 & 6.0 & 5.6 & 12.8 & -0.4 & +7.2 & +7.6 & \\
\hline \multicolumn{9}{|l|}{ Peat mosses } \\
\hline Centre, grazed & 33 & 88.4 & 80.7 & 69.8 & -7.7 & -10.9 & -3.1 & \multirow[t]{2}{*}{-2.4} \\
\hline Centre, ungrazed & 38 & 89.8 & 85.8 & 81.2 & -4.0 & -4.7 & -0.7 & \\
\hline \multicolumn{9}{|l|}{ Pasture } \\
\hline Centre, grazed & 28 & 0.0 & 0.0 & 1.1 & 0.0 & +1.0 & +1.0 & \multirow[t]{2}{*}{$+0.6^{*}$} \\
\hline Centre, ungrazed & 16 & 0.1 & 0.6 & 1.5 & +0.5 & +0.9 & +0.4 & \\
\hline
\end{tabular}

Differences between 1995 and 2007 were tested with paired Wilcoxon rank sum tests: $* P<0.05 ; * * P<0.01 ; * * * P<0.001 .1995,2001$, 2007: values in the respective year. $d_{01-95}$ : difference of the value $(2001)$ and the value $(1995)=$ change from 1995 to 2001 . $d_{07-01}$ : difference of the value (2007) and the value $(2001)=$ change from 2001 to 2007 . $d_{\mathrm{d}}$ : difference of $d_{07-01}$ and $d_{01-95}$ which shows if change has accelerated or decelerated. $d_{\text {dgrazed }}-d_{\text {dungrazed }}$ with significance level: shows differences in the development of grazed and ungrazed patches

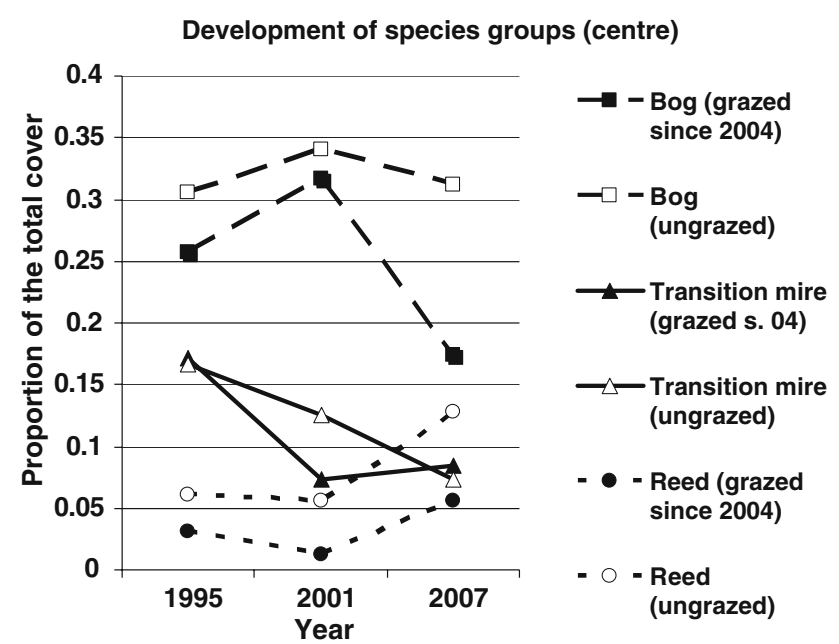

Fig. 3 Changes in the proportion of species groups in the vegetation of grazed and ungrazed patches in the non-forested centre of the mire

i.e. through shorter grazing periods adjusted to the phenology of reed. In addition, restoring the water regime and preventing further nutrient imports might improve the resistance of the vegetation against disturbance effects. Unless these measures are successful, grazing should be stopped. The vegetation monitoring program should be continued as a basis for future decisions.
Acknowledgments We thank O. Wildi, E. Feldmeyer and U. Graf for their constructive comments. We are also grateful to S. Dingwall for linguistic improvements.

\section{References}

Baumberger E (1911) Kurze Darstellung der geologischen Geschichte des Geländes zwischen Emme und Oenz. Mitt. Nat.forsch. Ges. Bern xx:198-209

Bokdam J, Gleichman JM (2000) Effects of grazing by free-ranging cattle on vegetation dynamics in a continental north-west European heathland. J Appl Ecol 37:415-431

Bragazza L (2008) A climatic threshold triggers the die-off of peat mosses during an extreme heat wave. Glob Chang Biol 14:26882695

Edom F, Dittrich I, Goldacker S, Kessler K (2007) Die hydromorphologisch begründete Planung der Moorrevitalisierung im Erzgebirge, in Praktischer Moorschutz im Naturpark Erzgebirge/ Vogtland und Beispiele aus anderen Gebirgsregionen: Methoden, Probleme, Ausblick., Sächsische Landesstiftung Natur und Umwelt (eds), Dresden, 19-32

Grossenbacher K (1980) Die Hoch- und Übergangsmoore des Kantons Bern: eine Übersicht. Mitt. Nat.forsch. Ges. Bern $37: 81-130$

Güsewell S (2003) Management of Phragmites australis in Swiss fen meadows by mowing in early summer. Wetl Ecol Manage 11:433-445

Güsewell S, Klötzli F (1998) Abundance of common reed (Phragmites australis), site conditions and conservation value of fen meadows in Switzerland. Acta Bot Neerl 47:113-129 
Güsewell S, Pohl M, Gander A, Strehler C (2007) Temporal changes in grazing intensity and herbage quality within a Swiss fen meadow. Bot Helv 117:57-73

Haslam SM (1972) Phragmites communis Trin. J Ecol 60:585-586

Höhn-Ochsner W (1963) Untersuchungen über die Vegetationseinhei-

ten und Mikrobiozönosen im Chlepfimoos bei Burgäschi/ Solothurn. Mitt. Nat.forsch. Ges. Bern Solothurn 21

Kooijman AM, Bakker C (1994) The acidification capacity of wetland bryophytes as influenced by simulated clean and polluted rain. Aquat Bot 48:133-144

Küchler M (2008) Software VEGEDAZ. Programm für die Erfassung und Auswertung von Vegetationsdaten. Update 2008. Beratungsstelle für Moorschutz, Eidg. Forschungsanstalt WSL, Birmensdorf

Küchler M, Ecker K, Feldmeyer-Christe E, Graf U, Küchler H, Waser LT (2004) Combining remotely sensed spectral data and digital surface models for fine-scale modelling of mire ecosystems. Commun Ecol 5:55-68
Landolt E (1977) Ökologische Zeigerwerte zur Schweizer Flora. Veröff. Geobot. Inst. ETH Zürich

Landolt E (1991) Gefährdung der Farn- und Blütenpflanzen in der Schweiz mit gesamtschweizerischen und regionalen roten Listen. BUWAL, Bern

Middleton BA, Holsten B, van Diggelen R (2006) Biodiversity management of fens and fen meadows by grazing, cutting and burning. Appl Veg Sci 9:307-316

Olde Venterink H, Vittoz P (2008) Biomass production of the last remaining fen with Saxifraga hirculus in Switzerland is controlled by nitrogen availability. Bot Helv 118:165-174

Stammel B, Kiehl K, Pfadenhauer J (2003) Alternative management on fens: response of vegetation to grazing and mowing. Appl Veg Sci 6:245-254

Venables WN, Ripley BD (2002) Modern applied statistics with S. Springer, New York

Von Büren G (1949) Der Burgäschisee. Mitt. Nat.forsch. Ges. Bern $6: 1-82$ 